\title{
Nursing Care Satisfaction among Patients Infected with Covid-19: A Turkish Perspective
}

\author{
Handenur Gündoğdu ${ }^{1}$, Fatma Tanrıkulu ${ }^{1}$, Funda Erol ${ }^{2}$ (D), Ferhat Koç ${ }^{3}$ (D), \\ Dilek Yılmaz $^{4^{*}}$ iD, Yurdanur Dikmen ${ }^{1}$ iD
}

\begin{abstract}
The aim of this study was to determine the satisfaction with nursing care among patients diagnosed with Covid-19 and related factors.

Materials and Methods. The study was conducted between June and July 2020. The population of the study consisted of 102 patients treated in the Covid-19 clinics of the University Teaching and Research Hospital. The data were collected using the Newcastle Satisfaction with Nursing Care Scale with a total of 19 items, and the Patient Description Form designed to record the sociodemographic characteristics and medical histories. The data were evaluated using the program package IBM SPSS 20.0. To test the significance of the difference between two independent groups, the Student's t-test was used, and the one-way ANOVA was used to test the significance of the difference between more than two groups.

Results. The results showed that most patients were satisfied with nursing care. A higher level of satisfaction was seen in patients treated in the Covid-19 intensive care units, those with chronic conditions, and those who received information about their health state from nurses. Patients' family type, sharing fears and worries with nurses, getting information from nurses and the quality of nursing care were the variables significantly associated with patient satisfaction with nursing care.

Conclusions. Satisfaction with nursing care among Covid-19 patients was moderate. When nurses use effective communication skills to meet patients' care needs, provide patients with adequate information, allow them to express their feelings, and keep them safe, this will further enhance patient satisfaction.

Keywords

Coronavirus Infections; Nursing Care; Patient Satisfaction

${ }^{1}$ Department of Nursing, Faculty of Health Sciences, Sakarya University of Applied Sciences, Sakarya, Turkey

${ }^{2}$ Vocational School of Health Services, Sakarya University of Applied Sciences, Sakarya, Turkey

${ }^{3}$ Sakarya University Training and Research Hospital, Sakarya Provincial Health Directorate, Republic of Turkey Ministry of Health, Sakarya, Turkey

${ }^{4}$ Department of Nursing, Faculty of Health Sciences, Bursa Uludag University, Bursa, Turkey

*Corresponding author: dilekk@uludag.edu.tr
\end{abstract}

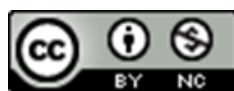

Copyright $\odot$ Handenur Gündoğdu, Fatma Tanrıkulu, Funda Erol, Ferhat Koç, Dilek Yılmaz, Yurdanur Dikmen, 2022

\section{Introduction}

The novel coronavirus infection (Covid-19) appeared at the end of 2019, and quickly spread throughout the world [1]. The World Health Organization has declared Covid-19 a pandemic; by that time, nearly 40 million people had already been infected, and approximately $1,175,000$ people had lost their lives to this illness. In Turkey, 368,513 people recovered, and 10,027 people died of the infection $[2,3]$. Despite all the measures taken, the virus continues to spread from person to person, and the numbers are increasing daily. For this reason, Covid-19 has come to pose a threat to both societies and health systems on an international scale [4].

From the beginning of modern nursing to the present days, nurses have taken on important responsibilities in fighting against epidemics, preventing and controlling infections, reducing mortality rates, and speeding up the recovery process [5]. In such extraordinary situations, the need for health care services increases and the necessity of nursing care has been shown [6]. In today's pandemic, nurses show great devotion in providing health care services, and their care and management roles as well [7]. In the clinical environment, nurses have a place in the holistic care of patients undergoing treatment in emergency departments, pandemic clinics and, especially, in the intensive care unit [6].

Caring, which is the essence of nursing, is at the same time a force for recovery, and, without care, treatment is impossible [8]. Therefore, an increase in the quality of 
patient care has a positive effect on the patient's recovery process. The most important indicator of the quality of care is patient satisfaction, the accord between the patient's expectations and the care received [9]. In addition, it has been reported that a patient who is satisfied with the health care given is affected positively by the treatment, and this shortens their hospital stay. Thus, the quality of care and patient satisfaction are important measures in the development of health and wellbeing [10]

Patient satisfaction depends on the availability of health care service, its continuity, presentation, and characteristics of healthcare providers such as their competency and communication; it may also be affected by the patient's sociodemographic characteristics such as age, gender, and education level, as well as clinical experiences [11]. Thus, when examining studies on the determination of patient satisfaction with nursing care, it was noted that there were different conclusions about the relationship between patient satisfaction and patient characteristics [12-14]. Along with this, in the literature, there are studies on determining the levels of patient satisfaction with nursing care $[9,10,15]$; however, there are no studies on care satisfaction among patients with Covid-19.

The aim of this study was to determine the satisfaction with nursing care among patients diagnosed with Covid-19 and related factors.

\section{Materials and Methods}

\section{Study Design}

It is a descriptive cross-sectional study conducted between June and July 2020 in the Covid-19 pandemic clinics of the University Teaching and Research Hospital in Sakarya, Turkey.

The patients who were in the Covid-19 clinics for at least two nights, could speak and understand Turkish, had no communication problems due to a previous diagnosis of psychiatric illness, voluntarily participated in the study and were 18 years of age or older were selected for the research.

To calculate the sample size, power analysis was carried out to be used as a measure. The relevant calculation was made, using the power analysis and the sample size software program PASS 13.0 (PASS, Kaysville, Utah, USA). The study conducted by Aldemir K et al. [10] "Examination of Satisfaction from Nursing Care of Inpatients in the Surgical Clinics" was taken as a reference to determine the overall scale score in line with the literature. In that study, the mean Newcastle Satisfaction with Nursing Care Scale (NSNCS) score was found to be $65.76 \pm 11.27$. To calculate the sample, the formula $\mathrm{n}=\mathrm{SS}^{2} \times\left(\mathrm{Z}_{\alpha}+\mathrm{Z}_{\beta}\right)^{2} / \mathrm{d}^{2}$ was used. As a result of the power analysis conducted for this study, 92 patients were planned to be enrolled in the study, taking a basic power value of $80 \%$. During the indicated timeframe of the study, 102 out of 368 patients treated in the Covid-19 clinics of the University Teaching and Research Hospital met the inclusion criteria and were involved in the study.

\section{Instruments}

The Patient Description Form and NSNCS were used to collect data.

\section{Patient Description Form}

This form was created by the researchers and contained 16 questions on the patients' sociodemographic characteristics such as age, gender, and marital status, as well as their illness and hospital stay, such as total length of stay, clinic, and nursing care $[10,16,17]$.

\section{The Newcastle Satisfaction with Nursing Care Scale}

The NSNCS was developed by Thomas LH, McColl E, Priest J, Bond S and Boys RJ in 1996, and adapted to Turkish by Uzun Ö [16] and later by Akın S and Erdoğan S [17]. The scale consists of 19 items to determine satisfaction with nursing care and is a five-point Likert-type scale $(1=$ not at all satisfied, $2=$ barely satisfied, $3=$ quite satisfied, $4=$ very satisfied, $5=$ completely satisfied). The scores for all items were added together, and the total was calculated as a percentage. The scale had no cut-off point. A high total score indicated that patient satisfaction was high. The Cronbach's alpha of the satisfaction scale is 0.96 [17]. In this study, the Cronbach's alpha reliability coefficient of the scale was determined to be 0.96 .

\section{Data Analysis}

Data evaluation was performed using the program package IBM SPSS 20.0 (SPSS Inc., Chicago, IL, USA). Numerical values, percentages, means, and standard deviations were calculated for the data. The mean score for the NSNCS, which was used as a data collection instrument, was calculated, and a normality test was applied to the data to determine the conformity of the scale scores to normal distribution. Table 1 shows the results of the normality test relating to the distribution of the NSNCS scores.

Table 1. Results of the normality test concerning the Newcastle Satisfaction with Nursing Care Scale score distributions.

\begin{tabular}{lccccll}
\hline \multicolumn{7}{c}{ Kolmogrow-Smirnov Test } \\
\hline & $\bar{X}$ & SS & Z & $p^{*}$ & Skewness & Kurtosis \\
NSNCS & 61.77 & 16.23 & 1.157 & 0.00 & -0.404 & -1.150 \\
\hline
\end{tabular}

Examining the results of the Kolmogorov-Smirnov test for the scores given in Table 1, it was seen that the $\mathrm{p}$ value for the NSNCS score distribution was less than 0.05 $(\mathrm{p}<0.05)$. However, the skewness and kurtosis values were in the range of \pm 1.5 . The skewness and kurtosis values of close to 0 show that the data display a normal distribution, and a range of \pm 1.5 is accepted as normal distribution [18]. As the skewness and kurtosis coefficients, the score graphs and the sample group $(n=102)$ were adequate, the scores were accepted as having normal distribution in the analysis of nursing care satisfaction data. To test the significance of the difference between two independent groups, the Student's t-test was used, and the one-way ANOVA was used to test the significance of 
the difference between more than two groups. When there was a significant difference between groups in the ANOVA test, the post hoc comparison Tamhane's T2, Bonferroni tests and Welch's ANOVA were applied to determine which groups the difference was between.

\section{Results}

Table 2 shows the patients' sociodemographic characteristics and their views of their illness, the hospital and nursing care.

Table 2. Patients' descriptive characteristics $(n=102)$.

\begin{tabular}{|c|c|c|c|}
\hline Variables & Category & $\mathrm{n}$ & $\%$ \\
\hline \multirow{2}{*}{ Gender } & Female & 41 & 40.2 \\
\hline & Male & 61 & 59.8 \\
\hline \multicolumn{4}{|c|}{ The average age: $60.92 \pm 11.10$ years (min. $27-\max .82)$} \\
\hline \multirow{5}{*}{ Education status } & Literate & 18 & 17.6 \\
\hline & Primary school & 33 & 32.4 \\
\hline & Secondary school & 25 & 24.6 \\
\hline & High school & 13 & 12.7 \\
\hline & College or university & 13 & 12.7 \\
\hline \multirow{3}{*}{ Family type } & Nuclear family & 79 & 77.8 \\
\hline & Extended family & 18 & 17.6 \\
\hline & Single parent family & 5 & 4.6 \\
\hline \multirow{2}{*}{ Health insurance } & Yes & 98 & 96.1 \\
\hline & No & 4 & 3.9 \\
\hline \multirow{2}{*}{$\begin{array}{l}\text { Unit in which the } \\
\text { patient is hospitalized }\end{array}$} & Covid-19 clinic & 91 & 89.2 \\
\hline & Covid-19 ICU ${ }^{1}$ & 11 & 10.8 \\
\hline \multirow{2}{*}{ Length of hospital stay } & $2-5$ days & 70 & 68.6 \\
\hline & 6-10 days & 32 & 31.4 \\
\hline \multirow{2}{*}{ Chronic condition } & Yes & 30 & 29.4 \\
\hline & No & 72 & 70.6 \\
\hline \multirow{4}{*}{ Chronic conditions } & Hypertension & 10 & 33.3 \\
\hline & Diabetes mellitus & 8 & 26.7 \\
\hline & COPD* & 6 & 20 \\
\hline & Other** & 6 & 20 \\
\hline \multirow{2}{*}{$\begin{array}{l}\text { Getting information } \\
\text { from nurses }\end{array}$} & Yes & 97 & 95.1 \\
\hline & No & 5 & 4.9 \\
\hline \multirow{4}{*}{$\begin{array}{l}\text { Level of knowledge } \\
\text { given by nurses }\end{array}$} & Adequate & 62 & 60.8 \\
\hline & Undecided & 16 & 15.7 \\
\hline & Inadequate & 10 & 9.8 \\
\hline & Quite inadequate & 14 & 13.7 \\
\hline \multirow{4}{*}{$\begin{array}{l}\text { Nurses' } \\
\text { communication skills }\end{array}$} & Quite adequate & 13 & 12.7 \\
\hline & Adequate & 60 & 58.8 \\
\hline & Undecided & 21 & 20.6 \\
\hline & Inadequate & 8 & 7.9 \\
\hline \multirow{4}{*}{$\begin{array}{l}\text { Quality of the care } \\
\text { given by nurses }\end{array}$} & Quite adequate & 13 & 12.7 \\
\hline & Adequate & 62 & 60.8 \\
\hline & Undecided & 20 & 19.6 \\
\hline & Inadequate & 7 & 6.9 \\
\hline \multirow{4}{*}{$\begin{array}{l}\text { Sharing fears and } \\
\text { worries with nurses }\end{array}$} & No fears or worries & 10 & 9.8 \\
\hline & Yes & 72 & 70.6 \\
\hline & No & 3 & 2.9 \\
\hline & Partly & 17 & 16.7 \\
\hline \multirow{2}{*}{$\begin{array}{l}\text { Effect of the care given } \\
\text { by nurses on recovery }\end{array}$} & Quite & 78 & 76.5 \\
\hline & Partly & 24 & 23.5 \\
\hline \multicolumn{4}{|c|}{$\begin{array}{l}\text { Notes: } \\
1 \text { Intensive Care Unit; } \\
* \text { Chronic obstructive pulmonary disease; } \\
\text { ** Hypothyroidism, cardiac insufficiency, cerebrovascular disease, } \\
\quad \text { prostate cancer, lung cancer, sarcoidosis. }\end{array}$} \\
\hline
\end{tabular}

The mean age of participants was $60.92 \pm 11.10$ years; $59.8 \%$ of them were males; $32.4 \%$ of patients completed primary education, and $77.8 \%$ of participants had a nuclear family. Most patients $(89.2 \%)$ were treated in the Covid-19 clinics, $68.6 \%$ of patients stayed in hospital for 2-5 days, and $96.1 \%$ of patients had health insurance. In addition, $70.6 \%$ of patients had no chronic illness. Among those who had chronic diseases, the most frequently seen conditions were hypertension $(33.3 \%)$ and diabetes mellitus (26.7\%). Ninety-five point one per cent of participants received information regarding their health from nurses, and $60.8 \%$ of them found the level of information provided to be "adequate". Moreover, $58.8 \%$ of patients thought that the nurses' communication level was "adequate", and $60.8 \%$ of them thought that the quality of nursing care was "adequate". At the same time, $70.6 \%$ of participants shared their fears and worries with nurses, and $76.5 \%$ of them thought that the care given by the nurses "significantly contributed" to recovery (Table 2).

The converted total mean score for the level of satisfaction with nursing care was found to be $61.77 \pm 16.23$ (Min-26, Max-85).

Table 3 shows the patients' mean scores for the level of satisfaction with nursing care according to certain variables. There was found a statistically significant difference in the patients' mean NSNCS scores depending on the clinic where they were treated, the presence of chronic illness, the information they received from nurses on their health status ( $\mathrm{p}<0.05)$. A higher level of satisfaction was seen in patients treated in the Covid-19 intensive care unit, those with chronic illness, and those who received information on their health state from nurses.

There was a statistically significant difference in the patients' NSNCS mean scores depending on their family type ( $\mathrm{p}<0.05)$. According to statistical analysis, the satisfaction with nursing care among patients with an extended family was significantly higher as compared to those with a nuclear family (Table 3 ).

The patients' mean scores for the NSNCS were found to vary depending on the level of information nurses gave to patients about their health; this difference was found to be statistically significant between groups $(\mathrm{p}<0.05)$. According to statistical analysis, the difference between groups regarding the satisfaction with nursing care arose from the difference between patients who rated the level of information given by nurses as "adequate" and those who gave an evaluation of "undecided" or "inadequate" (Table 3).

There was a statistically significant difference between the patients' NSNCS mean scores depending on their level of communication with nurses $(\mathrm{p}<0.05)$. There was found a statistically significant difference in the mean scores for satisfaction with nursing care between patients who thought that the nurses' communication level was "quite adequate" and those who rated it as "undecided" or "inadequate". At the same time, the mean scores for satisfaction with nursing care among patients who thought that nurses' communication level was "adequate" were significantly higher as compared to patients who rated it "undecided" or "inade- 
Table 3. Comparison of the patients' mean Newcastle Satisfaction with Nursing Care Scale scores according to certain variables $(n=102)$.

\begin{tabular}{|c|c|c|c|}
\hline Variables & $\begin{array}{c}\text { NSNCS } \\
\mathrm{X} \pm \mathrm{SS}\end{array}$ & $\begin{array}{l}\text { Statistical } \\
\text { Analysis }\end{array}$ & $\begin{array}{l}\text { Post- } \\
\text { Hoc Test }\end{array}$ \\
\hline \multicolumn{4}{|l|}{ Gender } \\
\hline Female & $60.90 \pm 15.82$ & \multirow{2}{*}{$\begin{array}{l}\mathrm{t}^{\mathrm{I}}=-0.443 ; \\
\mathrm{p}=0.659\end{array}$} & \\
\hline Male & $62.36 \pm 16.61$ & & \\
\hline \multicolumn{4}{|l|}{ Age } \\
\hline $18-65$ & $59.38 \pm 16.28$ & \multirow{3}{*}{$\begin{array}{l}\mathrm{F}^{\mathrm{II}}=2.040 \\
\mathrm{p}=0.135\end{array}$} & \\
\hline $66-79$ & $64.86 \pm 15.24$ & & \\
\hline $80-99$ & $66.72 \pm 15.95$ & & \\
\hline \multicolumn{4}{|l|}{ Education status } \\
\hline Literate & $65.77 \pm 16.10$ & \multirow{5}{*}{$\begin{array}{l}\mathrm{F}^{\mathrm{II}}=0.468 \\
\mathrm{p}=0.759\end{array}$} & \\
\hline Primary school & $59.78 \pm 17.87$ & & \\
\hline Secondary school & $60.88 \pm 15.20$ & & \\
\hline High school & $60.92 \pm 15.63$ & & \\
\hline College or university & $63.84 \pm 15.86$ & & \\
\hline \multicolumn{4}{|l|}{ Family type } \\
\hline Nuclear family ${ }^{a}$ & $59.94 \pm 16.56$ & \multirow{3}{*}{$\begin{array}{l}\text { Welch=4.948; } \\
\mathrm{p}=0.031\end{array}$} & \multirow{3}{*}{$\mathrm{b}>\mathrm{a} I I I$} \\
\hline Extended family ${ }^{b}$ & $70.77 \pm 12.16$ & & \\
\hline Single parent family & $58.20 \pm 15.12$ & & \\
\hline \multicolumn{4}{|l|}{ Health insurance } \\
\hline Yes & $61.70 \pm 16.31$ & \multirow{2}{*}{$\begin{array}{l}\mathrm{t}^{\mathrm{I}}=-0.216 \\
\mathrm{p}=0.830\end{array}$} & \\
\hline No & $63.50 \pm 16.36$ & & \\
\hline \multicolumn{4}{|c|}{ Unit in which the patient is hospitalized } \\
\hline Covid-19 clinic & $60.42 \pm 16.49$ & \multirow{2}{*}{\multicolumn{2}{|c|}{$\begin{array}{l}\mathrm{t}^{\mathrm{I}}=4.230 ; \\
\mathrm{p}<0.001\end{array}$}} \\
\hline Covid-19 ICU & $72.90 \pm 7.93$ & & \\
\hline \multicolumn{4}{|c|}{ Length of hospital stay } \\
\hline $2-5$ days & $62.78 \pm 14.93$ & \multirow{2}{*}{$\begin{array}{l}\mathrm{t}^{\mathrm{I}}=0.852 \\
\mathrm{p}=0.398\end{array}$} & \\
\hline 6-10 days & $59.56 \pm 18.85$ & & \\
\hline \multicolumn{4}{|l|}{ Chronic condition } \\
\hline Yes & $66.70 \pm 16.73$ & \multirow{2}{*}{$\begin{array}{l}\mathrm{t}^{\mathrm{I}}=2.007 ; \\
\mathrm{p}=0.047\end{array}$} & \\
\hline No & $59.72 \pm 15.68$ & & \\
\hline \multicolumn{4}{|c|}{ Getting information from nurses } \\
\hline Yes & $62.78 \pm 15.83$ & \multirow{2}{*}{$\begin{array}{l}\mathrm{t}^{\mathrm{I}}=2.861 ; \\
\mathrm{p}=0.005\end{array}$} & \\
\hline No & $42.20 \pm 11.60$ & & \\
\hline Level of knowledge $q$ & ven by nurses & & \\
\hline Adequate $^{\mathrm{a}}$ & $68.11 \pm 13.24$ & & \\
\hline Undecided $^{\mathrm{b}}$ & $48.56 \pm 10.21$ & Welch $=18.801$; & \\
\hline Inadequate $^{\mathrm{c}}$ & $44.40 \pm 12.33$ & $\mathrm{p}<0.001$ & \\
\hline Quite inadequate & $61.21 \pm 19.00$ & & \\
\hline Nurses' communicat & on skills & & \\
\hline Quite adequate $^{\mathrm{a}}$ & $72.61 \pm 15.92$ & & \\
\hline Adequate $^{\mathrm{b}}$ & $65.25 \pm 13.42$ & $\mathrm{~F}^{\mathrm{II}}=10.894$ & $\mathrm{a}>\mathrm{c}, \mathrm{d}^{\mathrm{IV}}$ \\
\hline Undecided $^{c}$ & $51.33 \pm 15.51$ & $\mathrm{p}<0.001$ & $\mathrm{~b}>\mathrm{c}, \mathrm{d}$ \\
\hline Inadequate $^{\mathrm{d}}$ & $45.50 \pm 14.53$ & & \\
\hline Quality of the care & ven by nurses & & \\
\hline Quite adequate $^{\mathrm{a}}$ & $74.00 \pm 8.38$ & & \\
\hline Adequate $\mathrm{b}$ & $64.27 \pm 13.80$ & Welch $=10.931$; & \\
\hline Undecided $^{\mathrm{c}}$ & $52.70 \pm 16.93$ & $\mathrm{p}<0.001$ & \\
\hline Inadequate $^{\mathrm{d}}$ & $42.85 \pm 19.26$ & & \\
\hline Sharing fears and $w$ & rries with nur: & & \\
\hline No fears or worries a & $67.50 \pm 14.05$ & & \\
\hline Yes $^{\mathrm{b}}$ & $64.68 \pm 15.03$ & $\mathrm{~F}^{\mathrm{II}}=6.947$ & \\
\hline No & $55.66 \pm 6.42$ & $\mathrm{p}<0.001$ & $a, b>c$ \\
\hline Partly ${ }^{c}$ & $47.17 \pm 15.92$ & & \\
\hline Effect of the care giv & n by nurses or & n recovery & \\
\hline Quite & $66.20 \pm 14.39$ & $\mathrm{t}^{\mathrm{I}}=5.686$ & \\
\hline Partly & $47.37 \pm 13.46$ & $\mathrm{p}<0.001$ & \\
\hline
\end{tabular}



${ }^{\mathrm{IV}}$ Bonferroni tests. quate" (Table 3).

There was a statistically significant difference between the patients' mean NSNCS scores depending on whether they shared their fears and worries with nurses $(p<0.05)$. According to the results of post hoc Bonferroni test, the mean scores for nursing care satisfaction among patients without fears or worries and those who shared their fears and worries with nurses were higher as compared to patients who thought they could "partly" share their fears and worries with nurses (Table 3 ).

There was found a significant difference between the mean NSNCS scores depending on the patients' views of the effect of nursing care on their recovery $(\mathrm{p}<0.05)$. The satisfaction with nursing care among patients who felt that nursing care was "greatly contributory" to the recovery process was significantly higher than that of patients who thought that it was "partially contributory" (Table 3 ).

At the same time, there was no statistically significant difference between the mean NSNCS scores depending on patients' gender, length of their hospital stay, or whether they had social security $(\mathrm{p}>0.05)$.

\section{Discussion}

In this study, conducted with the aim of determining Covid19 patients' views of and perceptions about satisfaction with nursing care, patient satisfaction with nursing care was found to be moderate. The findings supporting this result have been seen in other related studies $[10,19]$. However, in studies, including different sample groups, conducted by Şendir M et al. [11], Karaca A and Durna Z [20], the level of satisfaction with nursing care was high, while in studies conducted by Lotfi M et al. [15] and Eyasu KH et al. [13], it was low. The results obtained from these studies show that the level of patient satisfaction with nursing care varies. This may depend on factors such as differences in care standards of the institutions where the research is conducted, differences in the number of patients assigned to each nurse, or differences in the sample groups with which the research is conducted (such as the presence of chronic disease, length of hospital stay, etc.)

According to the findings of our research, patients treated in the intensive care unit and those with chronic conditions were more satisfied with nursing care than the others. Different results were obtained in other studies on the relationship between patient satisfaction and the clinic where the patient was treated. Karaca A and Durna Z [20] reported a higher level of satisfaction with nursing care in patients undergoing treatment in the emergency service unit, while Cerit B [21] concluded that there was no difference between the unit where the patient was treated and the level of satisfaction with nursing care. However, some studies found that satisfaction levels were higher in patients treated in surgical clinics as compared to those treated in internal medicine clinics [22]. The reason these results differed from the results of our study might be that our study was conducted with a sample of patients infected with the Covid-19 virus. In Covid-19 patients, symptoms can range from slight to serious, and especially in patients with chronic disease, the illness can be fatal. For this rea- 
son, people treated in the intensive care unit and those with chronic illnesses feel a greater need for nursing care [23]. Therefore, patients requiring more specific care may have a higher level of satisfaction with nursing care.

According to the results of this study, patients who stated that the level of information given to them by nurses about their health status was "adequate" had a higher level of satisfaction with nursing care. Previous studies have shown that the provision of information concerning patients' worries and questions on care procedures and the processes of diagnosis and treatment to patients and their relatives is an important factor in ensuring patient satisfaction [11, 13]. Karaca A and Durna Z [20] have reported that the information provided by nurses should be clear and concise, and that providing information plays an important role in patient satisfaction. Considering all these results together shows that it is important for nurses to ensure that patients are provided with sufficient information to increase their satisfaction with nursing care.

Nurses, talking to patients, using positive communication, listening to them, and giving them sufficient information, reduce patient stress and facilitate their adherence to treatment, and this is a prerequisite for patient satisfaction [20, 24]. In our study, patients who rated the nurses' communication skills as "quite adequate" and those who shared their fears and worries with nurses were found to have higher satisfaction with care. According to Lotfi M et al. [15], particular importance should be accorded to professional communication between nurses and patients, and the use of appropriate communication skills increases patient satisfaction with nursing care. These results show that the use of effective communication skills and providing patients with information has a great effect on satisfaction with nursing care.

Patients' individual characteristics, their expectations, and the presence of people from whom they can get support in the treatment process can affect their satisfaction with nursing care [22]. In our study, patients with extended families were found to have significantly higher satisfaction with nursing care than those with nuclear families.

According to this study, Covid-19 patients who thought that their nursing care was "quite sufficient" and those who stated that the effects of nursing care on their recovery was significant were more satisfied with nursing care. Similarly, Wojnicka AG et al. [22] have stated that good quality and individualized nursing care are directly related to satisfaction. Arslan S and Gürsoy [25], in a study conducted with 267 patients undergoing treatment in surgical units, found that the level of satisfaction with nursing care was higher in patients who thought that nursing care was "sufficient" and that it contributed to recovery. Thus, that in line with the results of our study and other studies, enquiring about patients' views of nursing care is thought to be a guide to determining patient satisfaction and making the necessary arrangements.

Different results have been reported on factors influencing satisfaction, as patient satisfaction is a multi-dimensional concept which is affected by patient and health care variables. This study found that patients' mean scores for satis- faction with nursing care did not vary depending on gender. Some studies have obtained similar results [11, 20, 21], while some authors have found that the level of satisfaction is higher in female patients than in males [10]. When evaluating the results of those studies and our findings together, the reason these results differed might be that gender might influence satisfaction, but the patients included in the research had different characteristics.

Our study found that the patients' mean nursing care satisfaction scores did not differ by age. After examining the results of related studies, it was seen that some studies obtained results similar to ours [15,21], while others, in contrast, found that satisfaction levels increased with age [22]. The reason that satisfaction levels in our and other studies varied with age might be due to differences in cultural values and differences in attitudes towards the events associated with an increase in patient maturity.

This study concluded that there was no difference between the patients' length of hospital stay and their mean scores for satisfaction with nursing care. However, some recent studies have found that patient satisfaction increases with shorter hospital stay $[10,26]$. In a study conducted by Wojnicka AG et al. [22], similarly to ours, there was found no significant difference between the length of hospital stay and satisfaction. Research results show that the length of hospital stay is a factor influencing the satisfaction level, but differences in sampling groups may affect this result.

\section{Limitations}

The research was conducted in a specific time period among the patients treated in the Covid-19 clinics of a single hospital who agreed to participate in the study. For this reason, the results obtained cannot be generalized and this constitutes a limitation to the study.

\section{Conclusions}

Determining satisfaction with nursing care in Covid-19 patients is an important indicator of the quality of nursing care and disease control. In this study, satisfaction with nursing care among Covid-19 patients was moderate, and the most important factors influencing patient satisfaction with nursing care were the quality of nursing care, positive communication with patients, giving patients an adequate level of information, and the patients' ability to share their fears and worries with nurses. Thus, the first step in increasing patient satisfaction with nursing care is to provide holistic and good quality care.

\section{Ethical Statement}

This research was conducted in accordance with the principles of the Declaration of Helsinki. Before the data collection stage, written permission was obtained from the NonInterventional Research Ethics Committee of the Medical Faculty of Sakarya University (Decision No: 71522473/ 050.01.04; Decision Date: 26 June 2020), and institutional approval was obtained from the hospital where the research was to be conducted. 


\section{Informed Consent}

Participants in the study were informed about the study, and their participation permissions were obtained.

\section{Acknowledgements}

The authors would like to thank the patients who participated in this study.

\section{Conflict of Interest}

The authors declare that there is no conflict of interest in publishing this research article.

\section{Financial Disclosure}

The author(s) received no financial support for the paper, authorship, and/or publication of this article.

\section{References}

[1] Doğan A, Karasu F. Covid -19 patient and nursing care: case report. Van Health Sciences Journal. 2020;13(Issue Covid-19):53-58. Available from: https://dergipark.org.tr/tr/download/articlefile/1099604

[2] Republic of Turkey, Presidential Digital Transformation Office. Coronavirus COVID-19 world map [cited 2020 Oct 29]. Available from: https://corona.cbddo.gov.tr/

[3] World Health Organization. WHO announces COVID-19 outbreak a pandemic [cited 2020 May 15]. Available from: https://www.euro.who.int/en/healthtopics/health-emergencies/coronaviruscovid19/news/news/2020/3/whoannounces-covid19outbreak-a-pandemic

[4] United Nations Development Program, Covid-19 Pandemic 2020 [cited 2020 Oct 29]. Available from: https://www.tr.undp.org/content/turkey/tr/home/coronavirus.html

[5] Çelik SŞ, Özbaş AA, Çelik B, Karahan A, Bulut H, Koç G, et al. COVID-19 pandemic process: Turkish Nurses Association [cited 2020 Oct 01]. Available from: https://www.thder.org.tr/uploads/files/thdcovid-19-faliyet-raporu-08.06.2020.pdf

[6] Baykara ZG, Eyuboglu, G. Nursing care in the COVID-19 pandemic. Gazi Journal of Health Sciences. 2020;5:9-17. Available from: https://dergipark.org.tr/tr/download/articlefile/1273340

[7] International Council of Nurses. ICN calls for global unity and solidarity to support nurses and other healthcare workers fighting the COVID-19 pandemic. 2020 [cited 2020 June 10]. International Council of Nurses. Available from: https://www.icn.ch/news/icncalls-globalunity-and-solidarity-support-nurses-and otherhealthcare-workers-fighting
[8] Dinç L. The concept of caring and 1ts' moral component. Hacettepe University Faculty of Health Sciences Nursing Journal. 2010;17:74-82. Available from: https://dergipark.org.tr/tr/download/article-file/88519

[9] Kersu Ö, Mert Boğa S, Kosgeroglu N, Aydın Sayilan A, İlter G, Baydemir C. Determination of the relationship between perception of nursing quality and satisfaction status of patiens hospitalized in surgical services. Journal of Education and Research in Nursing. 2020;17:32-39. Available from: https://doi.org/10.5222/HEAD.2020.032

[10] Aldemir K, Gürkan A, Taşkın Yılmaz F, Karabey G. Examination of satisfaction from nursing care of inpatients in the surgical clinics. Journal of Health and Nursing Management. 2018;5(3):155-163. Available from: https://doi.org/10.5222/SHYD.2018.155

[11] Şendir M, Büyükyılmaz F, Yazgan İ, Bakan N, Mutlu A, Tekin F. Evaluation of experience and satisfaction with nursing care in orthopedic and traumatology patients. Florence Nightingale Journal of Nursing. 2012;20(1):35-42. Available from: https://fnjn.org/en/evaluation-of-experience-andsatisfaction-with-nursing-care-in-orthopedic-and traumatology-patients-16818

[12] Alasad J, Abu Tabar N, AbuRuz ME. Patient Satisfaction with nursing care. JONA: The Journal of Nursing Administration. 2015;45(11):563-568. Available from: https://doi.org/10.1097/NNA.0000000000000264

[13] Haile Eyasu K, Adane AA, Amdie FZ, Getahun TB, Biwota MA. Adult patients' satisfaction with inpatient nursing care and associated factors in an Ethiopian Referral Hospital, Northeast, Ethiopia. Advances in Nursing. 2016;2016:1-7. Available from: https://doi.org/10.1155/2016/6308617

[14] Koirala M, Koirala ML. Contributing factors for perceived satisfaction with nursing care among inpatients in general wards. Journal of Lumbini Medical College. 2016;3(2):34-37. Available from: https://doi.org/10.22502/jlmc.v3i2.69

[15] Lotfi M, Zamanzadeh V, Valizadeh L, Khajehgoodari M. Assessment of nurse-patient communication and patient satisfaction from nursing care. Nursing Open. 2019;6(3):1189-1196. Available from: https://doi.org/10.1002/nop2.316

[16] Uzun Ö. Determining the validity and reliability of the Turkish Form of the Newcastle Satisfaction Scale regarding the quality of nursing care. Turkish Journal of Nurses. 2003;54(2):16-24. Available from: https://toad.halileksi.net/sites/default/files/pdf/hemsirelik-bakim-kalitesi-ile-ilgili-newcastle-memnuniyetolceginin-turkce-formunun-gecerlilik-ve.pdf 
[17] Akin S, Erdogan S. The Turkish version of the Newcastle Satisfaction with Nursing Care Scale used on medical and surgical patients. Journal of Clinical Nursing. 2007;16(4):646-653. Available from: https://doi.org/10.1111/j.1365-2702.2006.01583.x

[18] Tabachnick BG, Fidell LS. Using multivariate statistics (5th ed.). Boston, MA: Allyn \& Bacon; 2007.

[19] Kayrakçı F, Özşaker E. Determination of the surgical patients' saticfaction levels from nursing care. Florence Nightingale Journal of Nursing. 2014;22(2):105-113. Available from: https://fnjn.org/en/determination-of-the-surgicalpatients-saticfaction-levels-from-nursing-care-1

[20] Karaca A, Durna Z. Patient satisfaction with the quality of nursing care. Nursing Open. 2019;6(2):535-545. Available from: https://doi.org/10.1002/nop2.237

[21] Cerit B. Level of patients' satisfaction with nursing care. Journal of Hacettepe University Faculty of Nursing. 2015;3(1):27-36. Available from: https://dergipark.org.tr/tr/download/articlefile/225596

[22] Gutysz-Wojnicka A, Dyk D, Cudak E, Ozga D. Measuring patient satisfaction with the Polish version of the Newcastle Satisfaction with Nursing Scale. Scandinavian Journal of Caring Sciences. 2012;27(2):311318. Available from: https://doi.org/10.1111/j.14716712.2012.01034.x
[23] Sharma S, Nuttall C, Kalyani V, Hemlata H. Clinical nursing care guidance for management of patient with COVID-19. Journal of the Pakistan Medical Association. 2020;70(Suppl 3)(5):S118-S123. Available from: https://doi.org/10.5455/JPMA.29

[24] Marhamati S, Amini M, Mousavinezhad H, Nabeiei P. Design and validating the nursepatient communication skills questionnaire. Journal of Health Management and Informatics. 2016;3(2):57-63. Available from: https://jhmi.sums.ac.ir/article_42667_3c1115b2fe30a42153215a754aaea744.pdf

[25] Arslan S, Gürsoy A. Determination of nursing care satisfaction of surgical patients [Master Thesis]. Karadeniz Technical University Health Sciences Institute; 2019.

[26] Sayin Y. Nursing care satisfaction of surgery patients. SOJ Nursing \& Health Care. 2016;2(2):1-8. Available from: https://doi.org/10.15226/2471-6529/2/2/00116

Received: $2021-10-19$

Revision Requested: 2021-11-23

Revision Received: 2021-11-25

Accepted: 2021-12-02 